Journal of Applied Pharmaceutical Science Vol. 6 (07), pp. 184-188, July, 2016

Available online at http://www.japsonline.com

DOI: $10.7324 / \mathrm{JAPS} .2016 .60727$

ISSN 2231-3354 (cc) BY-NC-SA

\title{
Potential radical-scavenging activity of Pouteria caimito leaves extracts
}

\author{
Cecilia Vilela França ${ }^{1}$, João Paulo Silvério Perfeito ${ }^{1}$, Inês Sabioni Resck ${ }^{2}$, Sueli Maria Gomes ${ }^{3}$, Christopher William \\ Fagg $^{3}$, Carlos Frederico Souza Castro ${ }^{4}$, Luiz Alberto Simeoni ${ }^{1}$, Dâmaris Silveira ${ }^{*}$ \\ ${ }^{1}$ Faculdade de Ciências da Saúde, Universidade de Brasília, Campus Universitário Darcy Ribeiro, Asa Norte, Brasília, DF, Brazil. ${ }^{2}$ Instituto de Química. \\ Universidade de Brasilia, Campus Universitário Darcy Ribeiro, Asa Norte, Brasília, DF, Brazil. ${ }^{3}$ Departamento de Botânica, Instituto de Ciências \\ Biológicas, Universidade de Brasília, Campus Universitário Darcy Ribeiro, Asa Norte, Brasília, DF, Brazil. ${ }^{4}$ Departamento de Ensino de Graduação, \\ Instituto Federal de Educação, Ciência e Tecnologia Goiano, Campus Rio Verde, Rod. Sul Goiana, Km 01, Setor Universitário Rio Verde, GO, Brazil.
}

\begin{tabular}{|c|c|}
\hline ARTICLE INFO & ABSTRACT \\
\hline Article history: & \multirow{9}{*}{$\begin{array}{l}\text { Pouteria caimito (Sapotaceae) is widely distributed throughout Latin America, including Brazil. The yellow } \\
\text { fruits, known as abiu, caimito, or abiurana, are eaten in natura or used to prepare desserts. In addition to being a } \\
\text { commercially available Brazilian fruit, } P \text {. caimito has also been used as a traditional medicine. Therefore, } \\
\text { hexane, ethanol, and aqueous extracts from its leaves were evaluated for radical-scavenging activity. Free } \\
\text { radical-scavenging activity was tested using the DPPH assay. Total phenolic and proanthocyanidin contents } \\
\text { were also determined. The aqueous extract comprised the highest total phenol and proanthocyanidin contents } \\
(173.6 \mu \mathrm{g} / \mathrm{mL}) \text { and showed the highest radical-scavenging activity }\left(\mathrm{ED}_{50}=36.1 \mu \mathrm{g} / \mathrm{mL} \text { ). Phytochemical analysis }\right. \\
\text { of the hexane extract allowed the isolation of spinasterol. We found a high correlation between total phenolic } \\
\text { and proanthocyanidin contents and radical-scavenging activity. To our knowledge, this is the first time } \\
\text { spinasterol has been isolated from } P \text {. caimito leaves. }\end{array}$} \\
\hline Received on: 02/02/2016 & \\
\hline Revised on: $16 / 03 / 2016$ & \\
\hline Accepted on: $24 / 05 / 2016$ & \\
\hline Available online: $28 / 07 / 2016$ & \\
\hline Key words: & \\
\hline Pouteria caimito, & \\
\hline $\begin{array}{l}\text { Sapotaceae, Cerrado, } \\
\text { spinasterol, anti-oxidante }\end{array}$ & \\
\hline activity. & \\
\hline
\end{tabular}

\section{INTRODUCTION}

Oxidative stress has been considered as a major cause of aging and various chronic and degenerative diseases. These conditions include inflammation, diabetes mellitus, cancer, heart disease, and neuronal degeneration, such as Alzheimer's disease and Parkinson's disease (Ng, et al., 2007). A general recommendation to reduce systemic oxidation processes involves increasing the intake of foods considered to be rich in antioxidant compounds (e.g. polyphenols and carotenoids) owing to their well-known health-giving effects. This recommendation led to

\footnotetext{
* Corresponding Author

Damaris Silveira, Faculdade de Ciências da Saúde, Universidade de Brasília, Campus Universitário Darcy Ribeiro, Asa Norte, Brasília, DF, Brazil.CEP 70910-900, +55 61 31071939.Email:damaris@unb.br
}

the identification of many plants having potential antioxidant activities (Katalinic, et al., 2006). Therefore, natural antioxidants from plant extracts have attracted growing interest due to consumer concern about the safety of the synthetic antioxidants in food. Pouteria caimito (Ruiz \& Pav.) Radlk. belongs to the Sapotaceae family and is commonly known as abiu, caimito, or abiurana. This species is widespread in South America (Luna, 2004), and can easily be found in Brazilian home gardens. The yellow fruits are eaten in natura or used to prepare desserts and ice cream. Additionally, several parts of $P$. caimito have been used as folk remedies, mainly to relieve body pain and aid in wound healing (Kramer, et al., 2002). The fruit pulp is mucilaginous and is eaten to relieve coughs, bronchitis, and other pulmonary complaints, while the latex is used as a vermifuge and a purgative. Also, it is applied to abscesses (Morton and Dowling, 1987). The Tikano people (Amazon native people) use $P$. caimito as a treatment to facilitate childbirth (Luz, 1996; Ruiz, et al., 2011). 
The ethanol extract of $P$. caimito leaves showed antimicrobial activity against Pseudomonas aeruginosa, Bacillus cereus, and Candida albicans (Kramer, et al., 2002). A bark extract was evaluated against Artemia salina larvae and showed no toxicity (Quignard, et al., 2003). The methanol extract from the bark was tested against Colletotrichum lindemuthianum, a fungus causing bean anthracnose; however, it did not show any antifungal activity (Pinto, et al., 2010). Peruvian rainforest inhabitants use the leaves of $P$. caimito to treat malaria. However, an in vitro evaluation of a crude hydro-ethanolic extract did not show any activity against Plasmodium (a chloroquine-resistant strain) or Leishmania (Kvist et al., 2006; Ruiz et al., 2011).

The aqueous extract of $P$. caimito leaves showed inhibitory activity against $\alpha$-amylase $\left(\mathrm{IC}_{50}=13.6 \mu \mathrm{g} / \mathrm{mL}\right)$, $\alpha$-glucosidase $\left(\mathrm{IC}_{50}=2.58 \mu \mathrm{g} / \mathrm{mL}\right)$ and tyrosinase $\left(\mathrm{IC}_{50}=50.0\right.$ $\mu \mathrm{g} / \mathrm{mL}$ ) (Souza et al., 2012a; Souza et al., 2012b).

A crude ethanol extract from leaves inhibited germination in Lactuca sativa and Lycopersicum esculentum. The germination inhibition ratios (GIR) at $4 \mathrm{mg} / \mathrm{mL}$ were $76 \%$ and $75 \%$, respectively (Condessa, et al., 2013). However, the extract did not inhibit the growth (radicle and hypocotyl elongation) of Phaseolus vulgaris (Morikawa, et al., 2012).

Lupeol, $\alpha$-amyrin, erythrodiol, and dammarendiol II were isolated from the benzene extract of the fruit (Pellicciari, et al., 1972). The fruits gave $\alpha$-copaene, hexadecyl acetate, palmitic acid (Maia, et al., 2003), and 5-caffeyoylquinic acid (Pontes, et al., 2002). The fruit contained 2-10 $\mathrm{mg} / 100 \mathrm{~g}$ of ascorbic acid (Canuto, et al., 2010; Jáuregui, et al., 2015). Taraxerol, taraxerol acetate, sitosterol, and erythrodiol were isolated from $P$. caimito bark (Ardon and Nakano, 1973). The major fatty acids derived from the fruit seed oil were palmitic and oleicacids (Schuch, et al., 1984).

Thus, $P$. caimito is an interesting species owingto its antioxidant and biological properties and should be thoroughly examined. The objective of this work therefore was to evaluate the hexane, ethanol, and aqueous extracts from $P$. caimito leaves byusing pre-screening procedures for Artemia salina toxicity and in vitro antioxidant models.

\section{MATERIAL AND METHODS}

\section{Plant material}

The leaves of $P$. caimito were collected at Pocrane, Minas Gerais, Brazil, in December 2005 and identified by Prof. S. M. Gomes. A voucher specimen was deposited at Herbarium of Universidade de Brasília (UB) (voucher number UB 27284).

\section{Extraction procedures}

The dried and powdered plant material (506.0 g) was macerated at room temperature for seven days (repeated three times) with hexane, followed by ethanol. After filtration, the solvents were removed under reduced pressure, at a temperature below $40{ }^{\circ} \mathrm{C}$, yielding $14.0 \mathrm{~g}$ of hexane and $28.4 \mathrm{~g}$ of crude ethanol extracts $(2.8 \%$ and $5.6 \%$ yield, respectively). The aqueous extract from $300.0 \mathrm{~g}$ of the plant material was obtained by infusion by using 3.0 L of distilled water. After filtration, the obtained infusion was lyophilized, yielding $23.2 \mathrm{~g}$ of aqueous extract ( $7.7 \%$ yield).

\section{Isolation procedures}

Hexane extract ( $8.5 \mathrm{~g}$ ) was chromatographed on silica gel 60 Merck, by using a hexane: ethyl acetate: methanol gradient. The obtained fractions were monitored by thin layer chromatography (TLC), performed on precoated ALUGRAM sil G Machery-Nagel silica gel (60/0.2 mm) plates, using anisaldehyde reagent to visualize the spots (Wagner and Bladt, 1996). After analysis by TLC, the obtained fractions were collected and 15 groups were formed. After purification, groups 1, 3, 5, and 6 were characterized by ${ }^{1} \mathrm{H}$ and ${ }^{13} \mathrm{C}$ NMR spectra analysis. ${ }^{1} \mathrm{H}$ and ${ }^{13} \mathrm{C}$ NMR spectra were obtained using Varian (7.05 T) MercuryPlus spectrometers, operating at $300 \mathrm{MHz}$ and by using $\mathrm{CDCl}_{3}$.

Group 1 (93.0 mg), eluted with hexane, gave a hydrocarbon mixture. Group $3(150.0 \mathrm{mg})$, eluted with hexane:ethyl acetate (9:1), was extracted with acetone, yielding $15.0 \mathrm{mg}$ of an amorphous white solid, which was characterized as a long-chain ester mixture. Groups 5 and 6 (438.0 $\mathrm{mg}$ ) were extracted with acetone: methanol (1:1), yielding $30 \mathrm{mg}$ of 1 .

\section{Brine shrimp lethality test (BST)}

The crude extracts were tested for brine shrimp lethality. The assay was performed according to a simplified Meyer's method (Meyer et al., 1982), with modifications. Briefly, encysted eggs of the brine shrimp Artemia salina L. (Maramar) were incubated in artificial sea water at $28{ }^{\circ} \mathrm{C}$. Samples were dissolved in $200 \mu \mathrm{L}$ of DMSO plus $20 \mathrm{~mL}$ of artificial seawater. Serial dilutions (triplicate) were prepared in the same solution. Metanauplius (10 units) was added to each set of tubes containing samples and the cultures were further incubated for $24 \mathrm{~h}$. Controls containing DMSO were included in each set of experiments. Potassium dichromate was used as the reference standard. $\mathrm{LD}_{50}$ (after $24 \mathrm{~h}$ ) was calculated by Probit analysis (Perfeito, et al., 2005).

\section{DPPH assay}

The free radical-scavenging activity of the plant extracts and standards was assessed based on Blois' method with slight modification (Yildirim, et al., 2001), using the stable 2,2-diphenyl1-picrylhydrazyl (DPPH) free radical. Butylated hydroxytoluene (BHT), a well-known and widely used synthetic antioxidant, was used as a positive control. DPPH $(2.0 \mathrm{mg})$ was dissolved in ethanol $(10 \mathrm{~mL})$ to obtain a final concentration of $500 \mu \mathrm{M}$. This solution was preserved in a dark flask at room temperature.

DPPH solution $(300 \mu \mathrm{L})$, prepared daily, was added to $300 \mu \mathrm{L}$ of each extract or BHT solution in various concentrations and placed in the dark at $25{ }^{\circ} \mathrm{C}$. After incubation for $30 \mathrm{~min}$, the absorbance of each solution was measured at $517 \mathrm{~nm}$.

A negative control was prepared using $300 \mu \mathrm{L}$ of the solution, previously obtained from each extract and $300 \mu \mathrm{L}$ of 
ethanol, to account for the pigments of the crude extracts. Absorbance values of the solutions were measured and subtracted from those obtained with DPPH.

Data were used to calculate the concentration necessary to consume one-half of the initial amounts of DPPH $\left(\mathrm{EC}_{50}\right)$. Each of the measurements described above was performed in at least three replicated experiments, and the results were reported as mean and standard deviation values. The results were expressed in $\mu \mathrm{g} / \mathrm{mL}$.

\section{Proanthocyanidin content}

Proanthocyanidin quantification was performed using an adapted vanillin/sulfuric acid method (Morais, et al., 1999). Briefly, extracts were dissolved in a $10 \%$ hydroethanolic solution at $1000 \mu \mathrm{g} / \mathrm{mL}$ concentration. An aliquot $(1 \mathrm{~mL})$ of these solutions was mixed with $2 \mathrm{~mL}$ of freshly made vanillin/sulfuric acid solution $(0.2 \mathrm{~g}$ of vanillin in $100 \mathrm{~mL}$ of $30 \%$ sulfuric acid) and incubated for 15 minutes at $25{ }^{\circ} \mathrm{C}$. The absorption was measured at $500 \mathrm{~nm}$. A calibration curve was constructed with catechin as a reference standard in the $1000-62.5 \mu \mathrm{g} / \mathrm{mL}$ concentration range. Results were expressed in $\mathrm{mg}$ equivalents of catechin per $g$ of extract.

\section{Total phenolic content}

The total phenolic content (TPC) was determined by the Folin-Ciocalteu method as previously described (Morais, et al., 1999; Souza, et al., 2007), with slight adaptation to the semi-micro scale. A 5\% aqueous solution of Folin-Ciocalteu reagent was prepared and $300 \mu \mathrm{L}$ was transferred to disposable semi-micro cuvettes, which contained aliquots of the extract solutions (100 to $200 \mu \mathrm{L}$ ). After 5 minutes, $300 \mu \mathrm{L}$ of an aqueous solution of sodium carbonate $(7.5 \%)$ was added and the final volume was adjusted to $900 \mu \mathrm{L}$ with water.

This mixture was incubated for 2 hours at $25{ }^{\circ} \mathrm{C}$. Absorbance was measured at $760 \mathrm{~nm}$. A calibration curve was constructed with gallic acid solutions in the $10-40 \mu \mathrm{g} / \mathrm{mL}$ concentration range.

The TPC was determined by interpolation of absorbance values with the calibration curve obtained $(\mathrm{TPC}=\mathrm{Abs} * 0.0072+$ 0.0029 ), with a correlation coefficient of 0.9956 , and detection and quantification limits of 0.5 and $1.5 \mu \mathrm{g} / \mathrm{mL}$ gallic acid, respectively. Results were expressed as $\mathrm{mg}$ equivalents of gallic acid (GAE) per g of extract.

\section{RESULTS AND DISCUSSION}

The NMR spectra of compound $\boldsymbol{I}$ showed a typical steroidal profile. In ${ }^{1} \mathrm{H}$ NMR spectrum, in addition to other signals, a multiplet at $\delta 3.57$, from hydrogen linked to $\mathrm{C} 3$ of the steroidal skeleton and two double doublets at $\delta 5.02$ and $\delta 5.16$, attributed to olefinic hydrogens,were observed. The ${ }^{13} \mathrm{C}$ NMR spectrum showed 29 signals (Table 1). A comparison of NMR spectra data with those reported in the literature (Villasenor et al., 1996) allowed identification of compound 1 as spinasterol.
Spinasterol (1): ${ }^{1} \mathrm{H}$ NMR $\left(300 \mathrm{MHz}, \mathrm{CDCl}_{3}\right): \delta(\mathrm{ppm})$ $0.54,3 \mathrm{H}, \mathrm{s}(\mathrm{H}-18) ; 0.79,3 \mathrm{H}, \mathrm{s}(\mathrm{H}-19) ; 0.80,3 \mathrm{H}, \mathrm{t}, \mathrm{J}=7.3 \mathrm{~Hz}(\mathrm{H}-$ $29) ; 0.84,3 \mathrm{H}, \mathrm{d}, \mathrm{J}=6.34 \mathrm{~Hz}(\mathrm{H}-26$ or 27$) ; 1.02,3 \mathrm{H}, \mathrm{d}, \mathrm{J}=6.58 \mathrm{~Hz}$ (H-21); 3.57, 1H, m (H-3); 5.02, $1 \mathrm{H}, \mathrm{dd}, \mathrm{J}=8.6 \mathrm{~Hz}(\mathrm{H}-22$ or 23$)$; 5.14 , IH, m (H-7); 5.16, IH, dd, $\mathrm{J}=8.5 \mathrm{~Hz}(\mathrm{H}-22$ or 23$) .{ }^{13} \mathrm{CNMR}$ $\left(75 \mathrm{MHz}, \mathrm{CDCl}_{3}\right)$ : see table 1 .

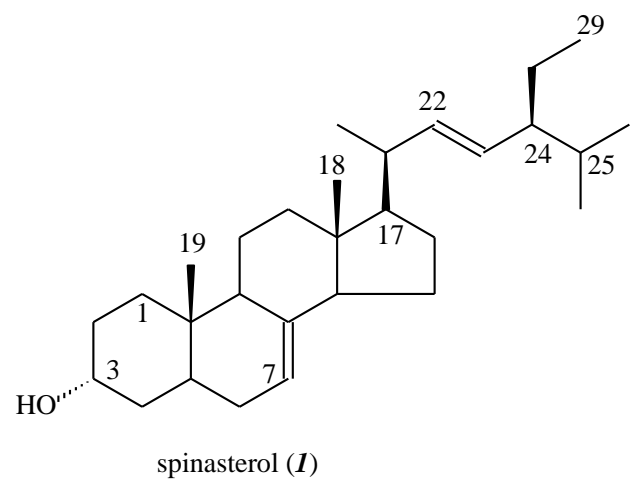

Table 1: $13 \mathrm{C}$ NMR data $(\delta, \mathrm{CDCl} 3)$ from compound 1 in comparison with literature (Villasenor et al., 1996).

\begin{tabular}{cccccc}
\hline 13C & spinasterol & $\mathbf{1}$ & $\mathbf{1 3 C}$ & spinasterol & $\mathbf{1}$ \\
\hline 1 & 37.11 & 37.11 & 16 & 28.49 & 28.51 \\
2 & 31.44 & 31.45 & 17 & 55.86 & 55.85 \\
3 & 71.04 & 71.06 & 18 & 12.03 & 12.04 \\
4 & 37.95 & 37.96 & 19 & 13.02 & 13.04 \\
5 & 40.23 & 40.22 & 20 & 40.82 & 40.84 \\
6 & 29.63 & 29.62 & 21 & 21.08 & 21.10 \\
7 & 117.43 & 117.45 & 22 & 138.15 & 138.17 \\
8 & 139.53 & 139.56 & 23 & 129.45 & 129.41 \\
9 & 49.42 & 49.41 & 24 & 51.22 & 51.23 \\
10 & 34.19 & 34.20 & 25 & 31.85 & 31.87 \\
11 & 21.52 & 21.53 & 26 & 21.34 & 21.37 \\
12 & 39.44 & 39.43 & 27 & 18.97 & 18.98 \\
13 & 43.27 & 43.27 & 28 & 25.28 & 25.4 \\
14 & 55.09 & 55.11 & 29 & 12.23 & 12.26 \\
15 & 22.98 & 23.00 & & & \\
\hline
\end{tabular}

Spinasterol has been investigated for its biological activities. At a concentration of $7.0 \mu \mathrm{g} / 0.1 \mathrm{~mL}$ acetone, this phytosterol decreased the incidence of skin tumours in mice by $55.6 \%$ (Villasenor and Domingo, 2000). Additionally, it showed antigenotoxic activity in both a micronucleus test and an in vivo method (Villasenor, et al., 1996), and increased the resistance of murine hippocampal HT22 cells to oxidative injury (Jeong, et al., 2010). Spinasterol was able to decrease plasma and liver cholesterol levels, causing no significant change in phospholipid levels (Uchida, et al., 1983). In addition, spinasterol showed inhibition of glomerular mesangial cell proliferation caused by high-ambient glucose, about 1,000 times higher than that of simvastatin, and reduced the serum triglyceride increase, renal weight, and urinary protein excretion in streptozotocin-induced diabetic mice (Jeong, et al., 2004). Furthermore, spinasterol suppressed pro-inflammatory enzymes and inflammatory mediators in BV2 microglial cells. This steroid also suppressed nitric oxide (NO), prostaglandin E2 (PGE2), tumour necrosis factor- $\alpha$ (TNF- $\alpha)$ and interleukin-1 $\beta$ (IL-1 $\beta$ ) (Jeong, et al., 2010). As expected, TPC, expressed as $\mathrm{mg}$ of gallic acid equivalent (GAE)/g extract, and proanthocyanidin content expressed as mg of 
catechin equivalent/g extract were affected by the extracting solvents, with the following order: hexane $\leq$ ethanol $<$ water (Karabegović, et al., 2014). The results are presented in Table 2.

Table 2: Total phenol and proanthocyanidin content and radical scavenge potential of Pouteria caimito leaves extracts.

\begin{tabular}{|c|c|c|c|}
\hline Sample & DPPH $^{a}$ & Proanthocyanidins ${ }^{b}$ & $\begin{array}{c}\text { Total } \\
\text { Phenol } \\
\text { Content }\end{array}$ \\
\hline Hexane extract & $597.7 \pm 9.3$ & $<$ L. D. ${ }^{\mathrm{d}}$ & $11.5 \pm 1.0$ \\
\hline Ethanol extract & $223.1 \pm 2.8$ & $<$ L. D. ${ }^{\mathrm{d}}$ & $46.5 \pm 6.5$ \\
\hline Aqueous extract & $36.1 \pm 0.8$ & $266.3 \pm 6.3$ & $173.6 \pm 4.6$ \\
\hline Ascorbic acid & $12.9 \pm 3.5$ & & \\
\hline BHT & $14.9 \pm 2.2$ & & \\
\hline
\end{tabular}

The TPC varied from 11.5 to $173.6 \mathrm{GAE} \mathrm{mg} / \mathrm{g}$. The aqueous extract had the highest phenol content. It is interesting to observe that the TPC value found in the leaf extract was greater than that found in fruit pulp. Contreras-Calderon et al. (2011) found $83 \mathrm{GAE} \mathrm{mg/100} \mathrm{mg}$ for the hydro-methanol (50\%) extract from fruit (Contreras-Calderón, et al., 2011), while Tuesta et al. (2014) found 7.81 GAE mg/100 mg for thehydromethanol (90\%) extract (Tuesta, et al., 2014).

The Artemia salina lethality test presents a correlation with an in vivo oral acute toxicity model (Parra, et al., 2001). Mathews (1995) proposed the use of the Artemia salina test as a model to evaluate compounds for their ability to protect against superoxide-mediated toxicity (Matthews, 1995). For both evaluations, an $\mathrm{LD}_{50}$ value lower than $1 \mathrm{mg} / \mathrm{mL}$ was considered active (Meyer, et al., 1982). Based on this classification, $P$. caimito leaf extracts can be regarded as non-toxic, as well as presenting no protective activity against superoxide-mediated toxicity.

On the other hand, by using a DPPH radical-scavenging test, one of the shortest tests available to investigate the overall hydrogen/electron-donating activity of single antioxidants, the scavenging ability of the aqueous extract, despite being lower than that of the controls (ascorbic acid and BHT), was found to be good. Moreover, it seemed that the inhibition percentage (antioxidant activity) and total phenolics could be correlated.

By comparison of the obtained values for antioxidant activity and phenolic content, it is possible to observe that as phenol content rises, radical-scavenging activity increases, as shown by other authors (Chaouche, et al., 2014; Haddouchi, et al., 2014; Karabegović, et al., 2014)

\section{CONCLUSION}

While studies of the antioxidant activity of $P$. caimito fruit can be found (Canuto, et al., 2010; Nascimento, et al., 2008), there are few studies involving $P$. caimito leaves. With regard to chemical composition, although spinasterol has been described as a common phytosterol of the Sapotaceae family (Khallouki, et al., 2003), as far we know, this is the first time this compound has been found in $P$. caimito. The presence of this compound can justify, at least in part, the biological activity shown by this plant species.

\section{ACKNOWLEDGEMENTS}

Financial support from The National Council of Technological and Scientific Development (CNPQ), The Brazilian Innovation Agency (FINEP), and The Foundation for Scientific and Technological Enterprises (FINATEC).

\section{REFERENCES}

Ardon A, Nakano T. Triterpenes from the bark of Pouteria caimito. Planta Med, 1973; 23(4):348-352.

Canuto GAB, Xavier AAO, Neves LC, Benassi MT. Physical and chemical characterization of fruit pulps from Amazonia and their correlation to free radical scavenger activity. Rev Bras Fruticult, 2010; 32(4):1196-1205.

Chaouche TM, Haddouchi F, Ksouri R, Atik-Bekkara F. Evaluation of antioxidant activity of hydromethanolic extracts of some medicinal species from South Algeria. J Chin Med Assoc, 2014; 77(6):302-307.

Condessa MB, Carvalho IAF, Santos BTA, Paula JE, Gomes SM, Silveira D, Simeoni LA. Effect of leaf extracts of three species of Pouteria (Sapotaceae) on the germination and growth of Lactuca sativa L. and Lycopersicum esculentum Mill. Rev Biol Farm, 2013; 9(3):1-18.

Contreras-Calderón J, Calderón-Jaimes L, Guerra-Hernández E, García-Villanova B. Antioxidant capacity, phenolic content and vitamin C in pulp, peel and seed from 24 exotic fruits from Colombia. Food Res Int, 2011; 44(7):2047-2053.

Haddouchi F, Chaouche TM, Ksouri R, Medini F, Sekkal FZ, Benmansour A. Antioxidant activity profiling by spectrophotometric methods of aqueous methanolic extracts of Helichrysum stoechas subsp. rupestre and Phagnalon saxatile subsp. saxatile. Chin J Nat Medicines, 2014; 12(6):415-422.

Jáuregui AMM, Ramos F, Ureta CAO. Evaluation of nutritional content of some food consumption by region of the jungle people. Horizonte Médico, 2015; 9(2):75-80.

Jeong G-S, Li B, Lee D-S, Kim KH, Lee IK, Lee KR, Kim YC. Cytoprotective and anti-inflammatory effects of spinasterol via the induction of heme oxygenase- 1 in murine hippocampal and microglial cell lines. Intern Immunopharm, 2010; 10(12):1587-1594.

Jeong SI, Kim KJ, Choi MK, Keum KS, Lee S, Ahn SH, Back SH, Song JH, Ju YS, Choi BK, Jung KY. alpha-Spinasterol isolated from the root of Phytolacca americana and its pharmacological property on diabetic nephropathy. Planta Med, 2004; 70(8):736-739.

Karabegović IT, Stojičević SS, Veličković DT, Todorović ZB, Nikolić NČ, Lazić ML. The effect of different extraction techniques on the composition and antioxidant activity of cherry laurel (Prunus laurocerasus) leaf and fruit extracts. Ind Crops Prod, 2014; 54(2):142-148.

Katalinic V, Milos M, Kulisic T, Jukic M. Screening of 70 medicinal plant extracts for antioxidant capacity and total phenols. Food Chem, 2006; 94(4):550-557.

Khallouki F, Younos C, Soulimani R, Oster T, Charrouf Z, Spiegelhalder B, Bartsch H, Owen RW. Consumption of argan oil (Morocco) with its unique profile of fatty acids, tocopherols, squalene, sterols and phenolic compounds should confer valuable cancer chemopreventive effects. Eur J Cancer Prev, 2003; 12(1):67-75.

Kramer A, Mosquera E, Ruiz J, Rodriguez E. Ethnobotany and biological activity of plants utilized during pregnancy and childbirth in the peruvian amazon. http://labs.plantbio.cornell.edu/cubl/emanv4p31.html, 2002; 4(1):31.

Kvist LP, Christensen SB, Rasmussen HB, Mejia K, Gonzalez A. Identification and evaluation of Peruvian plants used to treat malaria and leishmaniasis. J Ethnopharmacol, 2006; 106(3):390-402.

Luna FMS. Ethnobotany of the communities of the upper Rio Nangaritza. Lyonia, 2004; 7(2):105-122. 
Luz PFL. 1996. Estudo comparativo dos complexos ritual e simbólico associados ao uso da Banisteriopsis caapi e espécies congêneres em tribos de língua Pano, Arawak, Tukano e Maku do noroeste amazônico. Master Degree, Universidade Federal do Rio de Janeiro, Rio de Janeiro.

Maia JGS, Andrade EHA, Zoghbi MGB. Volatiles from fruits of Pouteria pariry (Ducke) Baehni and P. caimito (Ruiz and Pavon.) Rdlkl. J Essent Oil-Bearing Plants 2003; 6(2):127-129.

Matthews RS. Artemia salina as a test organism for measuring superoxide-mediated toxicity. Free Rad Biol Med, 1995; 18(5):919-922.

Meyer BN, Ferrigni NR, Putnam JE, Jacobsen LB, Nichols DE, McLaughlin JL. Brine shrimp: a convenient general bioassay for active plant constituents. Planta Med, 1982; 45(5):31-34.

Morais SAL, Nascimento EA, Queiroz CRAA, Piló-Veloso D, Drumond G. Studies of polyphenols and lignin of Astronum urundeuva wood. J. Braz. Chem. Soc. , 1999; 10(6):447-452.

Morikawa CIO, Miyaura R, Tapia y Figueroa ML, Rengifo Salgado EL, Fujii Y. Screening of 170 Peruvian plant species for allelopathic activity by using the Sandwich Method. Weed Biol Manag, 2012; 12(1):1-11.

Morton JF, Dowling CF (1987). Fruits of warm climates, In Morton JF (ed), Creative Resource Systems.

Nascimento VE, Martins ABG, Hojo RH. Physical and chemical characterization of mamey sapota fruits. Rev Bras Fruticult, 2008; 30(4):953-957.

$\mathrm{Ng} \mathrm{LT}$, Wu SJ, Tsai JY, Lai MN. Antioxidant activities of cultured Armillariella mellea. Appl Biochem Microbiol, 2007; 43(4):444448.

Parra AL, Yhebra RS, Sardiñas IG, Buela LI. Comparative study of the assay of Artemia salina L. and the estimate of the medium lethal dose (LD50 value) in mice, to determine oral acute toxicity of plant extracts. Phytomedicine, 2001; 8(5):395-400.

Pellicciari R, Ardon A, Bellavita V. Triterpenes from Pouteria caimito. Planta Med, 1972; 22(2):196-200.

Perfeito JP, Santos MLS, Lopez KSE, Paula JE, Silveira D. Characterization and biological properties of Pouteria torta extracts: a preliminary study. Braz J Pharmacog, 2005; 15(3):183-186.

Pinto JMA, Souza EA, Oliveira DF. Use of plant extracts in the control of common bean anthracnose. Crop Protection, 2010; 29(8):838842 .

Pontes PV, Moreira RFA, Trugo LC, Maria CABD. The content of chlorogenic acids in tropical fruits. J Sci Food Agric, 2002; 82(10):1177-1181.

Quignard ELJ, Pohlit AM, Nunomura SM, Pinto ACS, Santos EVM, Morais SKR, Alecrim AM, Pedroso ACS, Cyrino BRB, Melo CS, Finney EK, Gomes EO, Souza KS, Oliveira LCP, Don LC, Silva LFR, Queiroz MMA, Henrique MC, Santos M, Pinto PS, Silva SG. Screenig of plants found in Amazonas State for lethality towards brine shrimp. Acta Amazonica, 2003; 33(1):93-104.
Ruiz L, Ruiz L, Maco M, Cobos M, Gutierrez-Choquevilca AL, Roumy V. Plants used by native Amazonian groups from the Nanay River (Peru) for the treatment of malaria. J Ethnopharmacol, 2011; 133(2):917-921.

Schuch R, Baruffaldi R, Gioielli LA. Fatty acid composition of brazilian plants. I. Stizolobium aterrimum Piper \& Tracy and Lucuma caimito Roem. seed oils. J Amer Oil Chem Soc, 1984; 61(7):1207-1208.

Souza CMM, Silva HR, Vieira-Jr GM, Ayres MCC, Costa CLS, Araújo DS, Cavalcante LCD, Barros EDS, Araújo PB, Brandão MS, Chabes MH. Total phenolics and antioxidant activity of five medicinal plants. Quim Nova, 2007; 30(2):351-355.

Souza PM, Elias ST, Simeoni LA, Paula JE, Gomes SM, Guerra ENS, Fonseca YM, Silva EC, Silveira D, Magalhaes PO. Plants from Brazilian Cerrado with potent tyrosinase inhibitory activity. PloS one, 2012a; 7(11):e48589.

Souza PM, Sales PM, Simeoni LA, Silva EC, Silveira D, Magalhães PO. Inhibitory activity of $\alpha$-amylase and $\alpha$-glucosidase by plant extracts from the Brazilian cerrado. Planta Med, 2012b; 78(04):393-399.

Tuesta G, Orbe p, Merino C, Rengifo E, Cabanillas B. Actividad antioxidante y determinación de compuestos fenólicos del caimito (Pouteria caimito), caimitillo (Chrsophylum sanguinolentum), guava (Inga edulis) y yarina (Phytelephas macrocarpa). Folia Amazónica, 2014; 23(1):87-92.

Uchida K, Mizuno H, Hirota K, Takeda K, Takeuchi N, Ishikawa Y. Effects of spinasterol and sitosterol on plasma and liver cholesterol levels and biliary and fecal sterol and bile acid excretions in mice. Jpn J Pharmacol, 1983; 33(1):103-112.

Villasenor IM, Domingo AP. Anticarcinogenicity potential of spinasterol isolated from squash flowers. Teratog Carcinog Mutagen, 2000; 20(3):99-105.

Villasenor IM, Lemon P, Palileo A, Bremner JB. Antigenotoxic spinasterol from Cucurbita maxima flowers. Mutation Res/Environ Mutagen Rel Subj, 1996; 360(2):89-93.

Wagner H, Bladt S. 1996. Plant Drug Analysis. Berlin: Springer- Verlag.

Yildirim A, Mavi A, Kara AA. Determination of antioxidant and antimicrobial activities of Rumex crispus L. extracts. J. Agric. Food Chem., 2001; 49(8):4083 -4089.

\section{How to cite this article:}

França CV, Perfeito JPS, Resck IS, Gomes SM, Fagg CW, Castro CFS, Simeoni LA, Silveira D. Potential radical-scavenging activity of Pouteria caimito leaves extracts. J App Pharm Sci, 2016; 6 (07): 184-188. 